Comparative Philosophy Volume 2, No. 2 (2011): 50-71

Open Access / ISSN 2151-6014

www.comparativephilosophy.org

\title{
DAOISM AS CRITICAL THEORY
}

\author{
MARIO WENNING
}

\begin{abstract}
Classical philosophical Daoism as it is expressed in the Dao-De-Jing and the Zhuang-Zi is often interpreted as lacking a capacity for critique and resistance. Since these capacities are taken to be central components of Enlightenment reason and action, it would follow that Daoism is incompatible with Enlightenment. This interpretation is being refuted by way of developing a constructive dialogue between the enlightenment traditions of critical theory and recent philosophy of action from a Daoist perspective. Daoism's normative naturalism does neither rest on a primitivist call for a return to the past, nor does it suggest future-directed activism. By way of reconstructing its descriptive, explanatory and emancipatory dimensions, it is shown that Daoism constitutes an alternative form of critical theory. In contrast to future-directed purposive action or blind rule-following, Daoism's key normative concept of "wu-wei" emphasizes effortless non-calculative responsiveness in the present. Drawing on recent insights in the philosophy of action, a reconstruction of wu-wei allows to conceive of a promising form of emancipatory agency.
\end{abstract}

Keywords: Daoism, critical theory, wu-wei, instrumental action, effortlessness, temporality of action

\section{INTRODUCTION}

The legend of the origin of the proto-Daoist text Dao-De-Jing (道德經) dates back to the historian Sima Qian (145-85 BC). It is likely to be more fiction than fact. ${ }^{1}$ However, even though the legend remains historically unverifiable, it is nevertheless important to recount since it has given rise to a philosophically rich effective history. Daoist philosophy is said to rest on an act of exchange. The sage Lao $\mathrm{Zi}$ was determined to leave the middle kingdom after a long and, despite dissatisfaction with the norms of his day, saturated life. He approached the Western border of the kingdom of Zhou where he encountered Yin $\mathrm{Xi}$, who was the ancient version of a

WENNING, MARIO: Assistant Professor, Philosophy Program, Macau University, China / Humboldt Research Fellow, University of Frankfurt, Germany. Email: mwenning@umac.mo

${ }^{1}$ Most recent scholars agree that the different versions of the Dao-De-Jing were probably collections of aphorisms edited by various people in the $4^{\text {th }}$ and $3^{\text {rd }}$ centuries AD. We do not possess any reliable information about the historical person $\mathrm{Lao} \mathrm{Zi}$. 
customs and border control officer. Yin $\mathrm{Xi}$ asked Lao $\mathrm{Zi}$ to pay his dues. Since the sage was not an affluent man and did not possess anything dispensable, he was politely asked to pay for his passage by writing down what he had discovered during his philosophical wayfaring. After giving in to the request, Lao $\mathrm{Zi}$ left the kingdom to move West where he died much later at the magnificent age of 160. According to this legend, it is thus only by accident, or, to be more precise, through a generous act of exchanging the right of passage for the codification of Daoist philosophy, that the 5000 words divided into the 81 chapters we know under the title of Dao-De-Jing have been passed down to us.

During his exile from Nazi Germany, the Marxist poet Bertholt Brecht carried a painting depicting the scene of Lao $\mathrm{Zi}$ riding a water buffalo towards the border with him. Brecht's captivating poem from 1938 about the "Legend of the Origin of the Book Dao-De-Jing on Lao Zi's Road into Exile" was circulated widely among those persecuted by totalitarian regimes. The poem sparked a sense of hope in the midst of historical catastrophe. Did Brecht's adaptation of the legend simply present an unwarranted and sufficiently exotic consolation for the victims of an atrocious history who, if they were lucky, could escape, or does it indeed contain a philosophically significant content, an explosive message in a bottle? When the boy accompanying Lao $\mathrm{Zi}$ was asked by the pragmatic gate keeper in Brecht's poem what the sage had discovered, the boy responds: "he learnt that soft water, by way of movement over the years, will grind strong rocks away. In other words: that hardness succumbs." ${ }^{2}$ Drawing on the at the time common trope of the power of water to overcome the seemingly greatest of obstacles, ${ }^{3}$ what Brecht's border-crosser Lao $\mathrm{Zi}$ had discovered was an understanding of what could be called "liquid resistance." In contrast to firm materials, formless water does not overcome obstacles by way of direct confrontation, but through seemingly unintended, effortless and unpredictable processes of emulation and changing course whenever necessary. Rather than provoking resistance through acts of direct engagement, water is efficacious in overcoming obstacles by way of yielding and acquiescing to them. It purifies itself by standing still and finds its way by floating to the lowest point. The captivating poem by Brecht and its equally rich effective history poses the vexing question: what is the critical potential of Daoist philosophy that motivated Brecht and other social critics identifying with the fate of the most abject, degraded and precarious forms of existence to be swayed

\footnotetext{
${ }^{2}$ Bertolt Brecht (1981, 660-663). The cited quotation from stanza 5 reads in the original: „Daß das weiche Wasser in Bewegung/ Mit der Zeit den mächtigen Stein besiegt. / Du verstehst, das Harte unterliegt.“ See also Heinrich Detering (2008).

${ }^{3}$ The water imagery is developed in chapters 4, 7, 43 and, most extensively, in chapter 78 of the DaoDe-Jing: "In all the world, nothing is more supple or weak than water/ Yet nothing can surpass it for attacking what is still and strong./ And so nothing can take its place./ That the weak overcomes the strong and the supple overcomes the hard/ These are things everyone in the world knows but none can practice." (chapter 78, 81). Sarah Allan (1997) persuasively traces the way in which water serves as a root metaphor to illustrate the principles governing human conduct in classical, pre-Qin Chinese philosophical traditions.
} 
by its message, a message that seems radically different from the typical Marxist call to arms in the service of historical struggle for the sake of the worst-off?

Brecht's adaptation of Daoism seems all the more perplexing given the conception of Chinese philosophy in the West. One common critique leveled against Chinese philosophical traditions goes something like this. Rather than providing another alternative foundation for Enlightenment reason, Confucianism and Daoism are essentially incompatible with individual autonomy and equality, the pillars of the Enlightenment project. The alleged deficit is then attributed to a difference in philosophical outlook. The age of critique, announced in a tone of philosophical audacity from the Neo-Copernican Kant, claims philosophical singularity and superiority with regard to his East Asian contenders. While Western philosophical traditions in the Enlightenment tradition call into question established webs of authority, the emphasis on cosmic harmony in Confucianism and Daoism is said to rest on an acceptance of unquestioned relationships of power. In other words, harmony is emphasized at the expense of a capacity for individual resistance and critique. If autonomy and equality are the pillars of enlightenment reason, the capacity to resist is its muscle. If Daoism just gives in to established authorities, it does not possess the capacity of resistance, thus making it unsuitable for emancipation emphasized in the wake of the Enlightenment.

Following this line of critique, two specific strains of objections against Daoism's emancipatory potential and enlightenment deficit thus need to be addressed up front before discussing in what sense Daoism can be interpreted as a critical theory. One line of critique is addressed at Daoism's primitivist naturalism while the other set of objections focuses on the proposed technique of emulation. The first group of critics conceives of Daoism as a reactionary movement propagating a return to nature. Such movements claim that the present is fallen when compared to an allegedly earlier, blissful state in need of being restored once again. The emulation of a constantly changing yet static environment envisioned by Daoists is criticized as a form of imitation of, or a call for a return to, a primary state of nature. The natural world is being romanticized, critics contend, as idyllic and ethically superior. This line of critique, clearly mirroring Christian conceptions of a myth of the primal fall as one finds them in Western romanticism, hardly does justice to the gist of the normative ideals we find in the oldest Daoist texts. Rather than advocating a return to a simplicity that allegedly existed in some prior historical period, Lao $\mathrm{Zi}$ and Zhuang $\mathrm{Zi}$ draw on what they describe as "natural" processes in order to delineate structures of present flourishing in the midst of "historical" crises. Nature is not what happened prior to the fall from paradise to civilization, but the spontaneity which is ever again threatened to be covered up by webs of social domination and misguided authority.

That the pervasive reference to nature in Daoist texts is not the kind of naturalism the first group of critics take it to be becomes clear if we turn to the first readers of the classical Daoists who stressed that emulation is not to be misunderstood as imitation. Guo Xiang already emphasized in his commentary on the Zhuang-Zi (莊子) that blind imitation of an allegedly natural condition is useless, fruitless and harmful. 
Imitation is useless because the world is in constant flux and different times require different responses. Imitation is also fruitless since the very act of imitation presupposes a conscious effort, which stands in the way of achieving the naturalness that is being attributed to what is being imitated. And, finally, imitation is said to be harmful in that it manifests a constant striving to overcome one's limits. This overcoming rather than acknowledging stands in the way of optimal, we could also say, non-reified practices of self- other- and world-relationships. ${ }^{4}$ The term ' $z i$-ran' (自然), which is translated as 'natural', offers itself as a denominator for such processes of spontaneous flourishing. Just as optimal forms of action seem to be performed as if by themselves and without an ulterior end, nature also is not equipped with a fixed trajectory while revealing a sense of flourishing and fittingness. The reference to naturalness serves as a critique against artificial forms of "second nature" in the form of reified conceptions of morality and straining activism.

In the case of an occasional reference to an allegedly better past, for example to the utopian village in chapter 80 of the Dao-De-Jing, what is depicted is not a historical past of perfected human beings who live in harmony with nature. Rather, the images serve as mythic or utopian evocations of a mode of being and powerexecution which is significantly different and more sophisticated than that found in societies which use up all resources in acts of instrumental activism. ${ }^{5}$ In the case of the utopian village, what is depicted is not a primitive community before the fall. The city possesses tools such as ships and carts, armor and weapons, but they "have no reason to deploy them." "This city consists a group of people, which is technologically highly advanced while preserving the freedom to not use the technology at its disposal, to live a decelerated life in the present while leaving the technological choices at their disposal unused whenever their application is not absolutely necessary. They live in relatively small communities in order not to be governed by a distant government they do not have an obvious connection to. The imagination is used here as a laboratory to provide impulses in order to enrich conceptions of chosen, communal and sophisticated passivity in the present rather than primitive innocence or unreflective activism directed at the future.

Apart from the charge of primitive naturalism, a second, perhaps more forceful strain of objections against Daoism's critical potential concerns what is seen as the opportunistic strategy or set of techniques arising out of the ethics of emulation. While the first group of critics object to Daoism's alleged primitivism, the second group object to the proposed forms of emulation. This second strain of objections contends that Daoism essentially reconciles actors to the pathological structures of their age rather than empowering them to understand, oppose and, ultimately, transform or abolish these structures. This critique reflects a long tradition of

\footnotetext{
${ }^{4}$ Fung Yu-Lan $(1976,226-227)$.

${ }^{5}$ Viktor Kalinke $(1999,90)$ writes, "it is apparent that the emphasis of what has been does not aim at an objective historiography, but at the decelleration (Verzögerung) of action. A reflection and comparison with what is comparable is being called for. It has a psychological function, which is expressed in the German word 'nachdenken' (re-membering or after-thought)".

${ }^{6}$ Dao-De-Jing, trans. Ivanhoe (chapter 81).
} 
accusing Daoism of promoting a problematic form of quietism. Rather than resisting problematic processes of change, they are said to accept these phenomena as unchangeable. The best one can do, Daoists seem to suggest, is to use what is problematic but here to stay to one's advantage. The enfent terrible of contemporary philosophy Slavoi Zizek puts it as follows:

The recourse to Taoism or Buddhism offers a way out of this predicament which definitely work better than the desperate escape into old traditions: instead of trying to cope with the accelerating rhythm of the technological progress and social changes, one should rather renounce the very endeavor to retain control over what goes on, rejecting it as the expression of the modern logic of domination - one should, instead, "let oneself go," drift along, while retaining an inner distance and indifference towards the mad dance of the accelerated process, a distance based on the insight that all this social and technological upheaval is ultimately just a non-substantial proliferation of semblances which do not really concern the innermost kernel of our being... One is almost tempted to resuscitate here the old infamous Marxist cliché of religion as the "opium of the people," as the imaginary supplement of the terrestrial misery: the "Western Buddhist" meditative stance is arguably the most efficient way, for us, to fully participate in the capitalist dynamics, while retaining the appearance of mental sanity. If Max Weber were to live today, he would definitely write a second, supplementary, volume to his Protestant Ethic, entitled The Taoist Ethic and the Spirit of the Global Capitalism. ${ }^{7}$

While Zizek agrees that Daoism is not a form of primitivist romanticism, he argues that contemporary appropriations of Eastern thought, in particular Daoism, are a psychic symptom of neoliberal capitalism rather than promising conceptual and practical tools to understand and transform it. Rather than coming to terms with the accelerating logic of late modern societies, Daoist patterns of action, on Zizek's account, at best help to wander at ease within these pathological structures. They keep up the illusion of equanimous mental sanity in the midst of catastrophic madness.

Just as the charge against Daoism's alleged primitivism, Zizek's interpretation seems mistaken to me. It might be a legitimate response to certain "Eurodaoist" forms of lifestyle philosophies and new age wisdom literature propagating that a spiritual change will automatically lead to a transformation of the environing system parameters. What the objection fails to acknowledge and do justice to, though, is the emancipatory impulse behind Daoism. Rather than opposing one's changing environment with outdated images of bliss, by emulating this environment in constantly readjusting ways like a river adjusts its course, actors reclaim naturalness in their action and become empowered. Such an empowerment does not proceed by mastering the world through one's purposive efforts, but emancipates itself by

\footnotetext{
${ }^{7}$ Slavoi Zizek (2001). Zizek missed the fact that Max Weber (1989) did indeed write a second less known sequel to the Protestant Ethic and the Spirit of Capitalism in which he explicitly addresses Confucianism and the heterodox dimensions of Daoism while arguing for their responsibility for the precarious condition of China around the turn to the $20^{\text {th }}$ century.

${ }^{8}$ Peter Sloterdijk (1989).
} 
responding to the environment in the form of adjusting to dynamic processes in refined and often subversive ways.

Perhaps the most prominent and promising critical concept of Daoism is the guiding conceptual metaphor of $w u$-wei (無爲). It captures what this liquid resistance means in terms of concrete actions. Wu-wei is commonly translated as "non-doing" or "non-action". Following Liu Xiaogan, we can say that "naturalness is the core value of the thought of Lao $\mathrm{Zi}$, while $w u$-wei is the principle or method for realizing this value in action." This essential action-theoretical concept fills an important lacuna in contemporary critical theory. A charitable reconstruction could be immensely productive in contemporary debates in critical theory and the philosophy of action developed in the contemporary analytic and continental traditions. ${ }^{10}$ Such a reconstruction would free philosophical Daoism from its alleged enlightenment deficit.

Even a cursory look at the writings of the classical Daoists Lao Zi and Zhuang Zi suffices to reveal their emancipatory potential. Due to their hermeneutic openness, Daoist sources have been interpreted at different times as primitivism, religious mysticism, military strategy, advice to emperors, manuals for religious initiation and self-cultivation, normative and epistemic relativism, precursors of postmodernism, anarchism, linguistic skepticism or simply as a collection of incoherent poetic sayings which defy the systematizing and rigorous logic common to mainstream contemporary philosophy. ${ }^{11}$ In what follows I would like to add one more reading and suggest that the spirit of Daoism is captured best when it is understood as a form of critical theory. Daoists propose a different enlightenment and a different critical theory, thereby presenting us with what Bert Brecht called a device of bringing forth a defamiliarization and estrangement (Verfremdungseffekt). This interpretative hypothesis can serve as a prolegomena to a future research project. To make such a project not only plausible but also fruitful, I would like to show that Daoism, understood as a distinctly other form of critical theory, is capable of providing impulses that could be taken up in addressing one of the most pressing issues facing critical theorists today.

Daoism, I argue, can be helpful in conceiving of a form of non-instrumental action and reawaken a sense of potentiality, which helps to uncover a blind spot at the basis of conceptions of time and action as we find it in contemporary critical philosophy. A charitable reinterpretation of the Daoist concept of wu-wei allows us to

\footnotetext{
${ }^{9}$ Xiaogan Liu $(1999,211)$.

${ }^{10}$ Edward Slingerland (2006) interprets the conception of wu-wei understood as effortless action. It might be argued that certain theories of action in the European canon point into similar directions. Aristotle's conception of praxis, for example, and its reception by Hannah Arendt and others come to mind. I will show at a different occasion that these conceptions retain the temporal framework governing purposive actions, motivating a more radical break such as the one provided by an updated account of Daoist effortless action.

${ }^{11}$ For a detailed account of the history of Daoism see Livia Kohn (2000), as well as Russell Kirkland (2004). For a systematic introduction see Hans-Georg Möller (2001).
} 
conceive of a form of practical reason and action, which embodies a promising alternative to instrumental rationality. A reorientation of critique resulting from a constructive engagement with Daoism would have to arise out of an acknowledgment that one of the underlying ideologies of modernity consists precisely in a problematic preoccupation with either the past or the future at the expense of acknowledging perfecting forms of effortless action as they reveal themselves in the present. To make this claim intelligible it is necessary to call to mind the basic structure of critical theory.

\section{THE THREEFOLD STRUCTURE OF CRITICAL THEORY}

First, it is necessary to outline what is meant by "critical theory" before pursuing the question whether, and in what sense, Daoism can legitimately be understood as another critical theory. Critical theory usually combines diagnostic, explanatory and emancipatory dimensions. In analyzing societies in times of crises and destitution, deeply seated pathologies are uncovered. These range from exploitation of underprivileged strata of the population and consumerism to the environmental and social costs of neoliberal market economies. Not only are these pathologies revealed, but their root causes and social functions are also being traced and, if possible, means of practically overcoming them are pointed out.

Pathologies are social and psychological deformations on a structural level manifesting themselves in social institutions, individual patterns of beliefs, motivations and practices. The pathologies which critical theory has been diagnosing can be summarized, following Marx, Lukacs and Weber, as a combination of reification, disenchantment and acceleration. In the process of increasingly understanding intersubjective-, self- and world-relationships primarily from the perspective of exchanging equivalent commodities on a market governed increasingly, and sometimes exclusively, by a competition for these commodities, individuals become systematically estranged from the objects they produce, the process of production, themselves, and from the community of fellow human beings. $^{12}$

The pathology of reification (Verdinglichung) arising from the exchange principle governing ever more dimensions of society has been analyzed, drawing on the early Marx and Lukacs, from a variety of perspectives. ${ }^{13}$ Originally reification referred to the process of making singular human beings and experiences similar and exchangeable by abstracting from their unique qualities. While the concept seemed outdated for a long time due to its implicit assumption of a human essence from which one could become estranged, it made an astonishing comeback. Whether it is a critique of the reification/distortion of communication, ${ }^{14}$ the reification of relationships of intersubjective recognition, ${ }^{15}$ the reification of gender roles ${ }^{16}$ or the

${ }^{12}$ Karl Marx (1973, 108-111).

${ }^{13}$ See for example Axel Honneth, (2005).

${ }^{14}$ Jürgen Habermas (1984).

${ }^{15}$ Axel Honneth (1996). 
reification of conceptions of the self, ${ }^{17}$ what is being criticized are relationships primarily controlled by a fixed logic of instrumental reason and strategic bargaining processes rather than mutual understanding, recognition, care for the self, love and other preconditions of leading a good life within the constraints of justice.

Apart from the attempts to shed light on reification as a major form of pathology in modern societies, it is a significant success of recent work in critical social theory to emphasize that not all pathologies of modernity can be reduced to intersubjective pathologies of communication and reification. ${ }^{18}$ People in late modern societies do not just suffer from being used rather than understood or being invisible rather than recognized. They also suffer from what Max Weber called 'disenchantment' (Entzauberung). In the process of increased rationalization, traditional sources of meaning that were sedimented in inherited religious traditions, social institutions and customs have lost their power in orienting lives.

Finally, the process that reification and the vanishing of resources of meaning have been engaged in is one of an increasing acceleration (Beschleunigung) in which, as Marx puts it, "everything that is solid melts into the air". We witness a progressively increasing speed not only of technological innovation, but of social change since the late medieval period. While there was an intergenerational speed of change in the early modern period, and a generational speed of change during classical and high modernity, late modernity is characterized by an intragenerational speed of change in which the basic parameters of coordinating one's life change within a lifetime. In this latest stage of acceleration, the only thing that is certain is that what was taken to be certain today might not be certain tomorrow. ${ }^{19}$ This acceleration is both subjectively experienced and corresponds to objective modes of accelerated life ranging from processing information, the transportation of goods and people, voting behavior to the change of significant others and professions. Increased change of environments and values undermines traditional forms of identity formation since actors are forced to constantly reassess and readjust their forms of life, practices and sets of convictions.

All three pathologies constitute forms of social injury. While the psychological impact of reification leads to systematic forms of forced inclusion or exclusion, of being restricted to or being left out of fixed identities, and the process of disenchantment corresponds to a sense of existential absurdity in a world devoid of binding resources of meaning, the pressures of increasing acceleration are experienced in terms of existential exhaustion and anxiety. As a consequence, there is an increased sense of superfluousness and being antiquated, a fear to be left behind in, or fall outside of the rushing hamster's wheel of late modern societies.

However distinct these pathologies might appear, it is crucial to notice that there is a close linkage between these three briefly outlined pathological tendencies of modern societies. Not only are reification, disenchantment and acceleration

\footnotetext{
${ }^{16}$ Judith Butler (1999).

${ }^{17}$ Michel Foucault (1977).

${ }^{18}$ See J.M. Bernstein (2001); Nikolas Kompridis (2006).

${ }^{19}$ Hartmut Rosa, (2005, chapter 5).
} 
historically connected, they also imply each other on a conceptual level. Reification consists in seeing the world primarily from the vantage point of being a means or a toolbox from which means can be utilized in order to bring about a desired end. In this objectifying process, the end justifies the variable means and is the only factor taken to be intrinsically valuable. This end, then, is understood as not presently realized but as a future possibility the reality of which depends on the implementation of one's plan of action. Bernard Williams, the eminent British moral philosopher, stresses this point by arguing that without projecting an aim into the future, life would become meaningless. He argues for "the idea of a man's ground projects providing the motive force which propels him into the future, and gives him a reason for living." 20 If it were the case that our very existence would be safeguarded only as long as we intentionally pursue future-directed goals and projects in increasingly rationalized ways, it would mean that actors would be doomed to be increasingly alienated from a present they could at best regard as offering instrumentally useful, but intrinsically insignificant means for a supposedly meaningful future. Seen from the temporal horizon of the actor engaged in instrumental reasoning and action, the present events, actions, objects and subjects lack any intrinsic value. They are regarded as merely "useful for" certain projects rather than significant in virtue of what they are. The moment a project is realized, the satisfaction vanishes since it is not futural anymore. By presupposing such a restricted conception of projective action as the reason for living, the present environment an actor navigates in is transformed into pure immanence in which prediction becomes possible to the point of resembling an analytic judgment: assuming that we know what we want, and if we can do what we want while nobody keeps us from doing it, what we want will become realized. Novelty is being reduced to the discovery of new implications of what has already been familiar. Effort is generated once we see the end of our action as external to our spontaneously generated attachments. It grows out of the attempt to realize the stipulated end in ever more innovative, efficient and predictable ways in which spontaneity is, at best, forced towards a goal. The goal at which effort is directed often drops out of focus during the acceleration process or it loses its appeal. It seems external to the actor who has been trapped in a means-ends apparatus. This rationalization process increasingly becomes independent from the specificity of ends pursued and impossible to get out of. With every rationalized act the actor moves deeper into the quicksand of a world of suppressed spontaneity.

The consequence of this seemingly autonomous rationalization process famously described by Weber as an "iron cage" is that the present is being downgraded as insignificant on its own terms when compared to the future gains one promises oneself as the payoff of one's actions. Processes of innovation become the norm and speed up because actors hope to do and achieve ever more goals in increasingly

${ }^{20}$ Bernard Williams $(1982,13)$. Harry Frankfurt objects to Williams on this point by arguing that "our interest in living does not commonly depend upon our having projects that we desire to pursue. It's the other way around: we are interested in having worthwhile projects because we do intend to go on living, and we would prefer not to be bored." Taking Ourselves Seriously \& Getting it Right (2006, 36$37)$. 
shorter segments of emptied time. Actors rush to a future, which can in principle never be actualized. Paul Virillio fittingly describes this blind acceleration process of chasing structurally elusive future goals in increasingly higher speeds of innovation adequately as a "rushing standstill". From within the "iron cage" of modernity true innovation, which would have to be different from mere acceleration or enhancement and would require deliberating about alternative present ends, seems increasingly impossible. ${ }^{21}$ The new is transfigured into the only variable that is to be expected. Instrumental action as the reified forgetfulness of the meaning resources of the present for the sake of the projected future thus seems without alternative. The consequence is what Hermann Lübbe refers to as a 'Gegenwartsschrumpfung', a continuing shrinking of the present under the complimentary pressures of the tendencies of melancholic musealization of irretrievably lost pasts and forced innovation to run after structurally elusive futures. ${ }^{22}$

The dilemma with which critical theorists see themselves confronted is that whatever emancipatory tendencies - be they introduced as forms of resistance, mutual understanding, recognition etc. - are being proposed as means for a future end, instrumental action is reenacted under a normative guise and the domination of the future over the rest of time is thus further sedimented. As soon as instrumental actors propose or just point to emancipatory forms of action, they replicate and reenact the same temporal logic that it originally diagnosed as the problem of modernity, i.e., the belief that the future can be mastered through acts of projective planning. The problem of this projective planning mentality is not that things often turn out differently than planned, but that the actor sidesteps and thereby undermines the significance of the present and sees it simply as something to be used for future ends. In other words, by downgrading the present including its modes of action to being "for the sake of the future," critical theory denigrates the present to the status of a prefuture, a state of emptiness that is used as a resource rather than lived in.

A theory exposing and explaining social pathologies is keen on pointing to the inescapable mechanisms preventing the emancipatory use of reason through action. Such an exclusive focus on the diagnosis and emergence of pathologies coincides with developing an ethics of melancholy that emphasizes the inescapable specter of instrumental reason. Looking back in a melancholy state of mind over the long history of failed revolutions, it only sees what has been irretrievably lost in the wake of histories of catastrophes. ${ }^{23}$ The present is now seen as an appendix to a past larger than life, an after-past. By replacing the search for an alternative mode of present potentiality with a focus on the traumatic experiences of history, it forecloses the possibility of emancipatory action in the present and thereby reverses the temporal logic of modernity. By replacing the infatuation of the projected future over the present, a new domination - that of the past over the present - is being introduced and sedimented. While the former domination - that of the future over the present -

\footnotetext{
${ }^{21}$ Paul Virillio (1999).

${ }^{22}$ Hermann Lübbe (1994).

${ }^{23}$ Gillian Rose (1979); Gregg M. Horowitz (2001).
} 
corresponded to forms of blind activism, the latter - that of the past over the present leads to a state of passivity, an inhibition, which replaces the engagement with the present for the contemplation of mnemonic art. The consequence is not a liberation of the past (which is in principle impossible) or a liberation of the present, but an extension of the temporal pressure put on the present. While the classical modernists only had to justify themselves with respect to the future, late modernists also have to justify themselves with respect to the past.

This detour was intended to show that the instrumental actor finds himself in a dilemma that seems impossible to get out off. The shrinking of the present arising out of instrumental action constitutes a theoretical as well as practical impasse. A transcultural engagement with Daoism understood as another critical theory could turn out to be fruitful given that it emerged within a cultural context in which instrumental action has not been the only or even primary form of action. First, however, it needs to be asked whether it is at all legitimate to interpret Daoism as another critical theory.

\section{DAOISM AS ANOTHER CRITICAL THEORY}

In the second part of the paper I will first show that Daoism can be understood as a critical theory and then discuss whether it offers an insight that could overcome the uneasy relationship between critical theory and emancipatory action with a focus on the present. The goal is to show that the proto-Daoists Lao $\mathrm{Zi}$ and $\mathrm{Zhuang} \mathrm{Zi}$, commonly referred to as "Lao-Zhuang", provide a promising path which points to an alternative approach of addressing the vexing problem of instrumental action expressing itself in the pathologies of reification, disenchantment and acceleration. At the risk of engaging in anachronistic hermeneutics by applying texts from a different tradition which date back two and a half-millennia, the benefits of tapping rich conceptual sources providing a new insight into entrenched philosophical preconceptions seem overwhelming. Compared to European traditions, Daoism's long history of addressing phenomena of reification and change in theoretical, as well as practical ways, provides an immense richness not only for a reorientation of critical theory, but also in terms of envisioning emancipatory practices. The insight into the fluidity of social dynamics and the fluid subjectivity of actors anticipates many of the developments of late modern societies. At the same time Daoism offers us correctives to these developments. The early Daoist acknowledgment of the value of idling and uselessness, for example, allows us to level a critique of the pathologies of reification, disenchantment and acceleration deriving from a reduction of action to instrumental action. A critical theory in the spirit of Daoism would not simply disclose pathologies. It would also offer constructive resources which allow us to critically address and, as far as possible, overcome these pathologies without providing yet another reifying project that sells out on the potentiality of the present for the sake of the future.

Before focusing on how Daoism could help to address the connection between suffering from reification, disenchantment and acceleration, let us first step back and 
consider the all but self-evident proposal to conceive of Daoism as a form of critical theory. I will only briefly mention the diagnostic and explanatory dimensions for the reasons that they are the weakest and least developed parts in Daoist thinking, while the emancipatory dimension offers a way to address the question concerning the difficulty arising from the attempt to overcome instrumental rationality without replicating its underlying temporal logic.

First, Daoism is critical in the most obvious and widely acknowledged sense in that it presents a response to the destitution of China during the late Zhou dynasty in which war and social disintegration threatened the stability of society. ${ }^{24}$ Apart from this historical reason, exposing certain parallels with today's crises-ridden global order, both $\mathrm{Lao} \mathrm{Zi}$ and $\mathrm{Zhuang} \mathrm{Zi}$ are critical of the philosophical attempts to address this destitution, especially the attempt of Confucius and his successor, Mencius. Whereas Confucius and his followers propagated the cultivation of the virtuous human being with the goal of integrating him or her into a hierarchically ordered social organism through the subjection to principles of love and filial piety, the Daoists pursued a conscious retreat from commonly accepted social norms and rejected the starting point of normative theory understood as outlining universal, context-independent principles of social obligation and cultivation more generally: "Filial piety, brotherliness, benevolence, righteousness, loyalty, trust, honor, integrity-for all of these you must drive yourself and make a slave of Virtue." 25 While the Confucians aim at cultivating the individual to fulfill the duties springing from his or her fixed position in the web of social relationships, the Daoists propagate an unlearning process with the indirect goal of interrupting webs of social integration, including the desire for social recognition, for the sake of cultivating spontaneity. The individual is strengthened in his or her capacity to resist with regard to commonly accepted values of the community. However, the liquid, readjusting self propagated by Daoism is not an autonomous, deliberative firm subject commonly known in the Western philosophical traditions. Rather, it is a flexible or liquid self, which refuses to adhere to context-independent moral principles while responding to its environment in emancipatory ways. ${ }^{26}$

By focusing on outlining context-independent moral obligations, Confucian benevolence only addresses the pathologies of the age at the surface level, while leaving the deeper causes of alienation from the dao, the patterns of spontaneous flourishing, untouched: "When the great Way is abandoned, there are benevolence and righteousness. When wisdom and intelligence come forth, there is great hypocrisy. When the six familial relationships are out of balance, there are kind parents and filial children. When the state is in turmoil and chaos, there are loyal ministers." 27 As a form of proto-ideology critique, Daoism thus reveals how moral systems of belief serve as justifications of the underlying pathological practices rather

\footnotetext{
${ }^{24}$ Hubert Schleichert and Heiner Roetz (2009, 113-114).

${ }^{25}$ Zhuang-Zi (1968, book 14, 156).

${ }^{26}$ The "postmodern" conception of such a liquid self is seen primarily as a problem rather than a potential by Bauman (2006) and Sennett (1998).

${ }^{27}$ Dao-De-Jing (2002, chapter 18).
} 
than adequately addressing and, wherever possible, transforming them. The point made by Daoists is that it is not helpful to change the moral convictions of the time as long as one does not also change the underlying practices.

In the earlier analysis of the logic of instrumental action we have seen that by way of trying to master the present for the sake of a future project, the openness of the present is closed and the present shrinks. Constant innovation becomes a means in order to desperately try to gather more experiences and rush after fugitive goals in every shorter time spans. Critical theory has been incapable of addressing the pathology of acceleration in theoretically plausible and practically promising ways by failing to see through the temporal structure underlying instrumental, purposive action. This becomes particularly obvious when we turn to the third dimension of a critical social theory, that of opening up or at least pointing to transformative dimensions. In order to distance itself from the norms prevalent in the society, critical theory in a Daoist spirit has to point to something that is not only significantly different, but also significantly better. Only when it is possible to disclose possibilities that promise to overcome or at least significantly ameliorate the diagnosed pathologies as forms of social injury are we dealing with a progressive rather than reactionary force. The emancipatory dimension distinguishes mere cultural critique from critical theory.

In what way, then, does a reconstruction of Daoist conception of the relationship between optimal action and time point towards a transformative potential in the present? A charitable reconstruction of the concept of wu-wei would, without doubt, have to abandon certain metaphysical background assumptions common to ancient Daoism. In particular it is necessary to dismiss the cosmological conception of a basic harmony of the cosmos as well as the possibility of retreating from societies, including the norms governing these societies. It is not plausible to assume that the moderns have simply lost the right path or dao, because this would presuppose that there once was or always is a right path one could be led astray from. Rather, we might say metaphorically that the dao itself has become astray to express that social structures take on pathological forms. In other words, many of the pathologies of late modern societies are not directly to be attributed to the decisions of individual actors but are structural dimensions governing all spheres of society as much as theses spheres are only reproduced through human action. Actors cannot simply leave behind an unhealthy for a healthy dao, but have to uncover dimensions within dao, dimensions pointing to forms of actions, which allow for flourishing and transformation from within. Given these ramifications, a charitable interpretation of $w u$-wei could provide valuable insights for contemporary action theory in the context of critical social theory. I have suggested that wu-wei, understood as pertaining to the form of an action performed in an effortless way, provides a radically different conception of optimal action from that of purposive, instrumental activity.

As a key normative concept, wu-wei could perhaps be better translated as, following Ames and Hall, "non-coercive action" or, following Eric Sean Nelson, as 
"effortless non-calculative responsiveness" 28 to avoid the passive and quietist implications associated with the literal translation "non-action" or "non-doing". 29 Since the term appears in many different contexts and different texts, it can at best serve as an umbrella concept covering a potentially unlimited set of practices, which have some things in common and diverge in other dimensions. It is fair to say that due to its high valuation in classical Chinese texts, activities or forms of responsiveness referred to as displaying the structure of $w u$-wei present an achievement. They are optimal forms of comportment. While they can be cultivated, they don't follow the same means-end rationality which reduces the means to be only instrumentally useful and has a tendency to wear subjects out in accelerating processes of a forgetfulness of the present.

It has been argued by Chris Fraser, among others, that it is misleading to conceive of $w u$-wei as a form of effortless action and that it would be better to interpret it as non-intentional action instead. ${ }^{30}$ To understand why it is nevertheless justified to understand $w u$-wei as involving effortless dimensions rather than focusing on nonintentionality it is essential to distinguish two different senses of effort. This will allow us to avoid the misunderstanding that wu-wei would be an irrational, nonpurposive state of simply letting oneself go without conscious focus. Wu-wei interrupts a certain form of effortful striving. When referring to effort, we often conflate objective effort with subjectively experienced effort. While the former includes the exercise of physiological processes (physical effort) as well as thought processes (mental effort), the latter refers to the subjective feeling of exertion and exhaustion. ${ }^{31}$ When translating $w u$-wei as a form of "effortless non-calculative responsiveness" (rather than nonintentional action), what is meant is not the absence of objective effort, but a decreasing amount of subjectively experienced strenuousness. Such forms of performing an action without exhausting oneself coincide with the deliberate and often skilled performance of a practice. Often

\footnotetext{
${ }^{28}$ Ames and Hall (2003, 44-45); Eric Sean Nelson (2009, 294-316 and 396).

${ }^{29}$ For the purpose of this paper I will ignore the use of $w u$-wei as literally doing nothing and relegating tasks to subordinates in the context of good governance depicted in the figure of the emperor who, by relegating all authorities and responsibilities to his inferiors, constitutes the invisible and inactive center of power. See Roger Ames (1994).

${ }^{30}$ Chris Fraser proposes to adopt a diachronic model of action in which "acquisition begins with deliberate exertion, but eventually we internalize the skill and develop the ability to act automatically and sometimes effortlessly" (2007, 101). Such a quasi-Aristotelian two-phase model of action (first effortful acquisition and habituation, then effortless exertion of a skill) might fit some of the examples in Zhuang-Zi, including that of butcher Ding. It is not in line with wu-wei as the instantaneous transformation of the nature of one's character and action as it is introduced in the respective passages from Dao-De-Jing. In our context, the two-phase model would be incapable of explaining the transition from a perfectionist, future-oriented form of cultivation to an effortless and skillful engagement with the present. Effortless action is not the goal of causally necessary forms of antecedent acts of cultivation, but it constitutes a transfiguration of the very form of the action an actor is involved in. It could happen any moment and could also be lost again when replacing spontaneity with a blind following of rules.

31 The distinction is introduced by Brian Bruya in the introduction to the rich collection of interdisciplinary essays on effortless attention $(2010,5)$.
} 
effortless actions tend to coincide precisely with an increased form of identification with highly complex forms of skilled action ranging from playing chess and juggling to speaking a natural language fluently. These actions are intentional in the sense that when being asked why an actor engages in them, he could provide a reason for his action as an answer. ${ }^{32}$ However, when $w u$-wei-like actions are conducted well, the consciousness of these reasons and especially the conscious fixation on future goals, which needs to be actualized through significant degrees of subjectively felt exhaustion, drops out of the field of experience of the actor.

One classic example to illustrate the structure of $w u$-wei-like actions is the story of cook Ding mentioned in Zhuang-Zi. The cook perfected the skill of cutting up oxen by learning how to use a knife with the greatest subtlety, avoiding any unnecessary friction. Ding did so by "using his cultivated intuition rather than his eyes" to cut up the ox according to his joints, avoiding all unnecessary resistance and thereby transforming an instrumental skill into an effective and context-sensitive art, an ars contextualis. ${ }^{33} \mathrm{He}$ perfected the art of butchery to the point of not having to blindly follow rules in a subjectively as well as objectively (with regard to the sharpness of the blade of the knife) exhausting way. This does not mean that cutting up the ox does not confront the butcher with challenges. Otherwise he would not even need a knife and would not be a master of his art. It also does not mean that Ding could not provide reasons for what he is doing. After all, he explains his philosophy of intuitive mastery to Lord Wen-Hui. However, when challenges arise, Ding stops for a moment to "size up the difficulties" and focuses on the activity in the present in a slow and calm manner rather than wasting his energies in forms of overly strenuous and hasty acts of applying a context-independent method. The story does not simply illustrate the benefits of wu-wei-like action, but offers a normative model, which "goes beyond skill" and, in Lord Wen-Hui's words, illustrates "the secret of caring for life". ${ }^{34}$ This secret, we may infer, is that the mastery of practices does not rest on analyzing or reasoning from principles, but in spontaneously attending to a situation intuitively and with a high degree of effortless concentration and dedication.

What is significant for our context is the specific temporality of engaging in $w u$ $w e i$. What the concept wu-wei designates is a perfection in the moment of present action rather than a perfection the goal of which is being projected into the future. The vital organ of decision making processes is the heart-mind xin (心) rather than the disembodied intellect. "For the ancient Chinese," A.C. Graham remarks, "the heart, not the brain, is the organ of thought. Most men use it to plan ahead, but the sage uses it only to reflect the situation as it objectively is, before he responds. Like a mirror, it reflects only the present; it is not stuffed with past information which it

\footnotetext{
${ }^{32}$ The thesis that an action is distinct from a mere physiological occurrence in terms of the answer that would be given by an actor or observers about the intention embodied in the action is developed in G.E.M. Anscombe (1957).

${ }^{33}$ Roger T. Ames (1989).

${ }^{34}$ Zhuang-Zi (chapter 3).
} 
'retains' (ts'ang [cang 藏] 'stores, hoards') at the cost of being trapped in obsolete attitudes. The sage perceives and responds to every situation as new." 35

Seen from a temporal perspective, $w u$-wei is intended to free the future-creating presence as it discloses itself from the perspective of an actor who is pursuing his task in a skillful and whole-hearted fashion in the ever new and newly experienced present. The actor is fully absorbed into performing an action well to the point of forgetting himself, the passage of time, as well as extrinsic goals of the action. It is easy to see that an action carried out in this way is also self-rewarding while being indirectly efficacious. The actor forgets the passage of time and is not being inhibited by the anxiety connected to goal fixation while he might nevertheless indirectly realize goals which are important to him. Being in a state of fully absorbed, meaningful and skilled action includes a heightened responsiveness to the constantly changing potential of the context surrounding the action. Rather than acting only locally by detaching a certain task, instrument or goal from its context, the actor mirrors the situation in its entirety. By freeing the attention for the demands of the present moment from the weight of a recollected past and the demands of a not yet present future, it allows an action to be spontaneous rather than being guided by a fixed plan the goal of which is projected beyond the here and now. The actor is not wearing himself out in the process of being plagued by a deadline attached to his project, but exercises his energies efficiently in the mastery of the art of perfecting action.

Based on the concept of $w u$-wei, a critique of the temporal logic underlying instrumental action that is lacking in critical theory becomes possible. In contrast to the inactivity of an apathetic person, the actor practicing wu-wei engages the present in non-instrumental ways. Rather than limiting non-instrumental action to the aesthetic realm as has been common in the European tradition from Schiller until Adorno or that of intersubjectivity as in the tradition from Kant to Habermas and Honneth, the domains in which actions can be practiced in a wu-wei-like manner is virtually unlimited.

Drawing on insights arising from analytic philosophy of mind and action, Chris Fraser has shown that wu-wei can be understood as what John Searle refers to as "the Background". 36 The Background is a term of art referring to the various tacit capacities, abilities and know-how an actor always already draws on whenever performing an action. These unthematized background conditions allow for an action to be successful while facing real time challenges that could not be solved through slow acts of premeditation. Classic examples would be the intuitive operation of a car's transmission or speaking a language fluently. These actions are being performed without having to calculate which gear is appropriate for which speed or consciously having to apply the rules of grammar.

Fraser ultimately criticizes $w u$-wei-based normative accounts of action since they proclaim to do away with the kind of higher-level deliberation that he rightly

${ }^{35}$ A.C. Graham $(1983,9)$.

${ }^{36}$ Chris Fraser (2008). 
considers fundamental to engaging in moral reasoning and other practices. I agree with Fraser that it is necessary to account for these forms of intentional deliberation while I disagree with him in excluding higher order intentional deliberation from the realm of potentially wu-wei forms of activities. What Fraser's reductivist analysis of $w u$-wei understood as nonintentional action fails to see is that reasoning is an action as well, a thought-action. ${ }^{37}$ Thought actions also always presuppose a background of tacit assumptions, including normative assumptions, meanings and associations of concepts, etc. A contemporary reconstruction of the concept of wu-wei understood as effortless non-calculative responsiveness (rather than nonintentional action) can thus also be applied to cognitive thought-acts. In the mentioned story of butcher Ding as well as other stories, Zhuang $\mathrm{Zi}$ emphasizes that the person who knows what he is doing often engages in thinking before he makes his moves. However, such thinking does not decide between alternative courses of action by applying rules in judgment (bian 辩). Rather, as A.C. Graham points out, such a form of attentive thinking is an intuitive sorting out (lun 論). ${ }^{38}$ Accordingly, artificial forms of deliberation, which are nonspontaneous, strenuous and fixated on following predetermined principles and future goals, are then to be distinguished from those kinds of genuine thought-actions which are conducted in a skillful, responsive and spontaneous manner with a heightened attention for and awareness of the specific needs of the evolving present. Daoism would espouse the latter while dismissing the former practices. Free intentional deliberation consists in an open encounter with intentional contents. Searle's assertion that "intentionality reaches down to the bottom level of the voluntary actions" 39 thus needs to be extended by adding that spontaneity and effortlessness receptivity also reaches all the way up to the level of intentionality. ${ }^{40}$ Only by acknowledging that $w u$-wei potentially applies to all actions, including thought-acts, do we get an insight into the scope and impact of Daoist naturalism. Once we acknowledge that many of our thought contents, as Galan Strawson's puts it, "just happen", ${ }^{41}$ the question becomes whether we can make any general claims about how to relate to them responsively. Actors are not simply confronted with neutral, occurring episodes entering and leaving their field of attention, but stand to their streams of consciousness in a relationship that Harry Frankfurt aptly characterizes as one of caring. ${ }^{42}$ In the process of $w u$-wei-like action, the actor does not distinguish between an instrumental value of intermediary goals and an absolute value of the

\footnotetext{
${ }^{37}$ Christopher Peacocke (1999).

${ }^{38}$ See Angus C. Graham (1983, 7-8); for the meaning of 'lun' see also A.C. Graham (2004, 28).

${ }^{39}$ Cited by Fraser $(2008,90)$.

${ }^{40}$ The importance of spontaneity for intentional action and judgment has been worked out by John McDowell (1994).

${ }^{41}$ Galen Strawson $(2003,228)$. Strawson stresses that thought processes are not correctly characterized as primarily consisting of conscious actions as much as they are activities, thus echoing the literal translation of wu-wei as a form of non-doing or an "action which is not an action".

${ }^{42}$ Harry Frankfurt writes "In my view, it is only in virtue of what we actually care about that anything is important to us. The world is everywhere infused for us with importance; many things are important to us." (2006, 20); see also Frankfurt (1988).
} 
future, final goal. Rather, as Graham shows, the only imperative of the Daoist critic of imperatives is "respond with awareness of what is objectively so." "43 an action is performed in a $w u$-wei-like manner, the actor does not only, and not even primarily care for the realization of the goals of his action, but also cares about how well, in the sense of how attentive, the action leading to such a realization is being performed. Daoists agree that if an action is carried out well, the actor responds to streams of inherently interconnected mental and physical events in a focused and contextsensitive manner. He is in a state of acquiescence to the specificity of the task performed and the context in which it is performed. In other words, he stops to see these events as unacceptable intruders that need to be sorted out anxiously according to given rules and reified plans, but as providing occasions or invitations for actions, actions which are responsive, sensitive and focused.

The implications of conceiving of optimal intentional action as not being one of an overtaxing, future-directed effort, but one that effortlessly focuses on the demands of the present, are far reaching. An action, which is not based on the logic of striving for future goals but on performing a practice well in the here and now, is the most efficacious form of practice since it does not waste its energy in fruitless confrontation. This is not to say that wu-wei-like actions could not be executed quickly. Wu-wei concerns the form rather than the speed in which an action is carried out. Whether an action is being performed quickly or slowly does not determine whether it is performed in an absorbed and responsive way. Sitting still, for example in the context of meditation, can be non-wu-wei-like in involving a lot of effort when the person meditating forces himself to sit still for ulterior goals. The skilled mastery of the juggler over his cascades or the engagement in a lively conversation, on the other hand, might be performed quasi-automatically even if involving quick and spontaneous responses. Conscious deceleration, be it through eating in a slower pace or turning to meditation, might further perpetuate the temporal logic of the instrumental calculus as long as it is performed with too much effort and connected to a focus on an extrinsic concern. The efficacy of effortless action is not one measured by calculating future gains against present costs, but one that takes into account how far the acting individual is in fact in tune with the rhythm of his or her environment by responding to challenges of that environment as they arise in ever readjusting forms. Such a process of being "in tune" combines mastery and responsiveness, engagement and receptivity, order and spontaneity, purpose and disinterestedness. Effortless action is thus not subject to following a universal set of norms as the Confucians (or Kantians) would have it. Rather, a person performing actions well generates singular norms that arise from, and do justice to, the concrete situation (auto-nomous).

The state of mind that a person is in while exercising noncalculative and responsive action has been compared to what psychologists have described as "flow experience". Flowing action provides an antidote to the accelerating, reifying and disenchanting logic that drives instrumental action. It comes as no surprise that

${ }^{43}$ Graham (1983,11). 
Zhuang Zi's story concerning cook Ding's perfected carving of an ox serves as a prominent example in Mihaly Csikszentmihalyi's classic Flow: The Psychology of Optimal Experience in which ' $y u$ ' (御) is being translated as 'flow'. 44 Flow comes about when human actors are absorbed in the present tasks at hand. The present tasks at hand are seen as providing living potentials rather than dead means for ulterior ends. When actors in flow states are confronted by a challenging task, the completion of this task lets the actor forget the past and the future. Interrupting ordinary strenuous comportment, an actor undergoing flow experiences also overcomes a reified sense of self, thereby "dereifying" or liquifying, reenchanting, and decelerating his relationship to the objects he produces, himself, the act of production and his fellow human beings. Flow arises out of a balancing act that is in constant danger of collapsing either into becoming a rote routine or an overtaxing effort. The overtaxing effort brings forth unnecessary forms of reactions, while the rote routine lacks the sense of freedom and potential. The art of wu-wei thus consists in successfully striking and sustaining a balance between extreme effort and passive rule-following. If an actor is capable of sustaining such a balance, there is a harmony between his desires and will. In this sense $w u$-wei-kind of actions are free actions as they are characterized by Frankfurt: "a free act is one that a person performs simply because he wants to perform it. Enjoying freedom of action consists in maintaining this harmonious accord between what we do and what we want to do."45 As different as the underlying temporality is, the guiding ideal of effortless, attentive actions provides a surprising overlap with the guiding Western ideal of positive freedom.

Let me end by returning to the legend concerning the origin of the Dao-De-Jing. According to this legend, the book was written down by Lao Zi through his student as a form of road toll in order to pass the toll-keeper at the Han pass when moving West. It is an irony of history that perhaps the first critique of the principle of exchanging the present for the future was passed down to us based on an operation of exchanging the written word for the right of passage. Lao $\mathrm{Zi}$, the first critic of the assumption that we could once and for all fix the living knowledge necessary to traverse the changing way with timeless principles, ${ }^{46}$ paid for his final passage by writing down and thus codifying the idea according to which water defeats the stone. Walter Benjamin, perhaps the most Daoist member of the Frankfurt school of critical theory, wrote a brief commentary on Brecht's poetic image of this scene. The commentary stresses that Lao $\mathrm{Zi}$ 's friendliness and cheerfulness interrupted the principle of equivalent exchange by "rendering a great service as if it were trivial." We might also say, as if it were non-calculative, effortless and responsive. Lao $\mathrm{Zi}$, Benjamin continues, thus "places these world-historical days under the motto: 'All right-just a brief stop'." It is the act of an effortless giving and thereby interrupting the journey without leading to a standstill that is forcefully conjured up in this anecdote. Capturing the spirit and the

\footnotetext{
${ }^{44}$ Mihaly Csikszentmihalyi (2008, 255). See also Chris Jochim (1998).

${ }^{45}$ Harry Frankfurt $(2006,14)$.

46 "A Way that can be followed is not a constant Way. A name that can be named is not a constant name." Dao-De-Jing, trans. Ivanhoe (chapter 1).
} 
specific presenting temporality of effortlessness, Benjamin asks "and what use would his wisdom be if he who forgot the valley (which he had just looked on with pleasure again) when he rounded the next corner did not also forget his anxieties about the future almost as soon as he felt them?" ${ }^{47}$ Critical theory has yet to come to terms with the radical potential of such seemingly small, spontaneous, effortless, friendly, forgetful and anxiety-free acts in the midst of precarious times.

\section{ACKNOWLEDGEMENTS}

The paper has greatly benefited from discussions during the 2011 APA Committee Session "Constructive Engagement of Analytic and Continental Approaches in Philosophy: From the Point of View of Asian Philosophy" as well as the 2011 "Beijing Roundtable on Contemporary Philosophy". In addition to the participants of these discussions I would also like to thank the three anonymous referees from Comparative Philosophy for their insightful comments and suggestions on earlier drafts of this paper.

\section{REFERENCES}

Allan, Sarah (1997), The Way of Water and Sprouts of Virtue (Albany: SUNY Press). Ames, Roger (1994), The Art of Rulership (Albany: SUNY Press).

---- (1989), "Putting the Te Back into Taoism", in J. Baird Callicott and Roger T. Ames (eds), Nature in Asian Traditions of Thought. Essays in Environmental Philosophy (Albany: SUNY Press, 1989), 113-44.

Anscombe, G. E. M. (1957), Intention (Cambridge MA: Harvard UP).

Bauman (2006), Liquid Times: Living in an Age of Uncertainty (Cambridge: Polity).

Benjamin, Walter (2003), "Commentary on Poems by Brecht", in Selected Writings, vol. 4 (Cambridge: Harvard University Press), 215-50.

Bernstein, Jay M. (2001), Disenchantment and Ethics (Cambridge: Cambridge University Press).

Bewes, Timothy (2002), Reification, or the Anxiety of Late Capitalism (London: Verso).

Brecht, Bertolt (1981), Gesammelte Gedichte, vol. 2 (Frankfurt: Suhrkamp).

Bruya, Brian (ed.) (2010), Effortless Attention: A New Perspective in the cognitive Science of Attention and Action (Cambridge MA: MIT Press).

Butler, Judith (1999), Gender Trouble. Feminism and the Subversion of Identity (New York: Routledge).

Csikszentmihalyi, Mihaly (2008), Flow: The Psychology of Optimal Experience (New York: Harper Perennial Modern Classics).

${ }^{47}$ Walter Benjamin $(2003,248)$. 
Dao-De-Jing [The Daodejing of Laozi], trans. Philip J. Ivanhoe (2002), (Indianapolis: Hackett).

Dao-De-Jing [Dao De Jing. A Philosophical Translation], trans. Roger Ames and David Hall (2003), (New York: Ballantine).

Detering, Heinrich (2008), Bertolt Brecht und Laotse (Göttingen: Wallstein).

Foucault, Michel (1977), Discipline and Punish. The Birth of the Prison, trans. Alan Sheridan (New York: Pantheon).

Frankfurt, Harry (2006), Taking Ourselves Seriously \& Getting it Right (Stanford: Stanford University Press).

Frankfurt, Harry (1988), The Importance of What We Care About: Philosophical Essays (Cambridge: MA, Cambridge University Press).

Fraser, Chris (2008), "Wu-Wei, the Background, and Intentionality", in Bo Mou (ed.), Searle's Philosophy and Chinese Philosophy: Constructive Engagement (Leiden: Brill), 63-92.

Fraser, Chris (2007), "On Wu-Wei as a Unifying Metaphor", in Philosophy East and West, 57 (1): 97-106

Fung, Yu-lan (1976), A Short History of Chinese Philosophy. A Systematic Account of Chinese Thought from its Origins to the Present Day (New York: The Free Press).

Graham, Angus C. (2004), Later Mohist Logic, Ethics and Science (Hong Kong: The Chinese University Press).

Graham, Angus C. (1983), "Taoist Spontaneity and the Dichotomy of 'Is' and 'Ought',' in Victor H. Mair (ed.), Experimental Essays on Chuang-tzu (Honolulu: University of Hawaii Press, 1983), 3-23.

Habermas, Jürgen, Theory of Communicative Action (Boston: Beacon Press, 1984).

Honneth, Axel (1996), The Struggle for Recognition: The Moral Grammar of Social Conflicts (Cambridge: Polity Press).

Honneth, Axel (2005), Verdinglichung (Frankfurt: Suhrkamp).

Horowitz, Gregg M. (2001), Sustaining Loss. Art and Mournful Life (Stanford: Stanford University Press).

Jochim, Chris (1998), "Just Say No to 'No Self' in Zhuang Zi”, in Roger Ames (ed.), Wandering at Ease in the Zhuang Zi (Albany: State University of New York Press), 35-74.

Kalinke, Viktor (ed) (1999), Studien zu Laozi-Daodejing. Laozi-Daodejing. Eine Erkundung seines Deutungsspekturms. Anmerkungen und Kommentare, vol. 2, (Leipzig: Leipziger Literaturverlag).

Kirkland, Russell (2004), Taoism: The Enduring Tradition (London: Routledge).

Kohn, Livia (ed) (2000), Daoism Handbook (Leiden, Boston and Cologne: Brill).

Kompridis, Nikolas (2006), Critique and Disclosure (MIT Press).

Lao Zi (2002), The Daodejing of Laozi, trans. Philip J. Ivanhoe (Indianapolis: Hackett).

Liu, Xiaogan (1999), "An Inquiry into the Core Value of Lao Zi's Philosophy", in Mark Csikszentmihalyi and Philip J. Ivanhoe (eds.), Religious and Philosophical Aspects of the Lao Zi (Albany: SUNY Press), 211-37. 
Lübbe, Hermann (1994), "Gegenwartsschrumpfung,“ in Klaus Backhaus and Holger Bonus (eds), Die Beschleunigungsfalle oder der Triumph der Schildkröte (Stuttgart: Schäffer-Poeschel), 129-64.

Marx, Karl (1973), Economic and Philosophic Manuscripts 1844 (London: Lawrence \& Wishart).

McDowell, John (1994), Mind and World (Cambridge MA: Harvard University Press).

Möller, Hans-Georg, In der Mitte des Kreises (Frankfurt: Insel, 2001).

Nelson, Eric Sean (2009), "Responding with Dao: Early Daoist Ethics and the Environment", Philosophy East and West, 59 (3): 294-316.

Peacocke, Christopher (1999), Being Known (Oxford: Clarendon Press).

Rosa, Hartmut (2005), Beschleunigung (Frankfurt: Suhrkamp).

Rose, Gillian (1979), The Melancholy Science: An Introduction to the Thought of Theodor W. Adorno (New York: Columbia University Press).

Schleichert, Hubert and Heiner Roetz (eds) (2009), Klassische Chinesische Philosophie (Frankfurt: Klostermann).

Sennett, Richard (1998), The Corrosion of Character, The Personal Consequences Of Work In the New Capitalism (London: Norton).

Slingerland, Edward (2006), Effortless Action. Wu-wei As Conceptual Metaphor and Spiritual Ideal in Early China (Oxford: Oxford University Press).

Sloterdijk, Peter (1989), Eurotaoismus (Frankfurt: Suhrkamp).

Strawson, Galan (2003), "Mental Ballistics or the Involuntariness of Spontaneity", in Proceedings of the Aristotelian Society, 103: 227-56

Virillio, Paul (1999), Polar inertia (London: Sage).

Weber, Max (1951), The Religion of China: Confucianism and Taoism, trans. Hans H. Gerth (New York: The Free Press).

Williams, Bernard (1982), Moral Luck (Cambridge: Cambridge University Press).

Zhuang-Zi [Chuang Tzu], trans. Burton Wason (1968) (New York: Columbia University Press).

Zizek, Slavoi (2001), "Self-Deceptions. On being tolerant — and smug". In Die Gazette, August 27. 